DOI.

https://doi.org/10.22219/fths.v3i2

Received: April 2020

Accepted: Mei 2020

Available online: Juli 2020

\title{
Uji Potensi Cracker Tepung Kulit Umbi Bawang Merah (Allium Ascalonicum) Sebagai Pangan Fungsional berAntioksidan dan Antihiperkolesterolemik
}

\author{
Rista Anggriani ${ }^{*}$, Rizki Khoirun Nisa ${ }^{1}$, Susi Oxyvia Rosenansi ${ }^{1}$, \\ Marcya Hulwatul Purtanti ${ }^{1}$, Warkoyo ${ }^{1}$ \\ ${ }^{1}$ Program Studi Teknologi Pangan, Fakultas Pertanian-Peternakan, Universitas Muhammadiyah \\ Malang, Malang, Indonesia \\ *Corresponding author email : $\underline{\text { rista@umm.ac.id }}$
}

\begin{abstract}
Diet is one of the causes of obesity and obesity, for example by consuming foods with high cholesterol levels such as fast food or fried foods, so it is necessary to find alternative non-fried processed products that have functional properties. Cracker as a non-fried processed product is fortified with shallot skin flour which has antioxidant activity. This research purpose is to determine the effect of adding shallot skin flour (3, 5, 10\%) to the cracker against total cholesterol reduction after 7 days of consumption. This research used laboratory experimental methods with pre post test design with control group. Each group consisted of 5 Wistar rats (2 control groups and 4 treatment groups) so total Wistar rats used were 30 rats. In addition, antioxidant activity was also tested. The results indicated that cracker in the P3 formula (10\% fortification of shallot skin flour) had high antioxidant activity of $68.90 \%$ and was able to decrease cholesterol with the highest precentage reduction of 10\% after 7 days of consumption. This cracker can be categorized as a functional food which has high antioxidants and antihypercholesterolemic activity.
\end{abstract}

Keywords: antioxidant, cholesterolc cracker, shallot skin flour

\section{PENDAHULUAN}

Kolesterol sebagai salah satu faktor penyebab Penyakit Jantung Koroner (PJK), lebih sering dikenal sebagai lemak. Tingkat kolesterol yang tinggi merupakan faktor PJK tersebut. Untuk itu setiap orang harus menjaga agar kadar kolesterolnya tetap normal sehingga menjaga resiko terkena PJK agar tetap rendah. Berdasarkan data WHO (World Health Organization) tahun 2011 memperlihatkan PJK sebagai penyebab kematian pertama di dunia, sedangkan di Indonesia merupakan penyebab kematian ke 8 (Depkes, 2007; WHO, 2015). Berdasarkan Riskesdas tahun 2013 prevalensi hiperkolesterolemia pada kelompok usia 25-34 tahun sebesar 9,3\% dan meningkat sesuai pertambahan usia hingga 15,5\% pada kelompok usia 55-64 tahun. Pada penduduk >15 tahun didapatkan kolesterol total abnormal sebesar 35,9\%. Pola makan menjadi salah satu faktor penyebab obesitas dan kegemukan, contohnya dengan konsumsi 
makanan dengan kadar kolesterol tinggi seperti fast food atau gorengan. Data Susenas modul konsumsi tahun 2009 menyebutkan bahwa gorengan merupakan salah satu jenis makanan praktis yang dipilih oleh 51\% rumah tangga di Indonesia.

Antioksidan merupakan senyawa yang dapat menghambat reaksi oksidasi, dengan cara mengikat radikal bebas dan molekul yang sangat reaktif. Salah satu bentuk senyawa oksigen reaktif adalah radikal bebas. Efektivitas antioksidan dalam menurunkan kadar kolesterol telah diteliti dalam penelitian Andriani (2007) yang menyatakan bahwa aktivitas antioksidan dari ekstrak betaglukan dapat mencegah tingginya lipid peroksida darah tikus. Begitu pula penelitian Marianti (2013) yang menyatakan bahwa aktivitas antioksidan madu Randu dapat menurunkan kadar kolesterol pada tikus percoban. Namun bahanbahan tersebut sulit didapatkan dan memiliki harga yang mahal. Antioksidan dapat ditemukan salah satunya ditemukan di kulit bawang merah (KBM). Terdapat beberapa senyawa bioaktif di ekstrak KBM diantaranya alkaloid, polifenol, saponin, flavonoid, steroid dan triterpenoid, kuinon serta seskuiterpen dan monoterpen. Berdasar nilai IC $_{50}$ nya, antioksidan pada ekstrak KBM termasuk kategori yang sangat aktif (Mardiah, dkk., 2017). Selain itu Rahayu, dkk (2015) menyatakan bahwa aktivitas antioksidan limbah KBM menunjukkan bahwa fraksi etil asetat memiliki potensi sebagai antioksidan lebih besar dibandingkan dengan fraksi air.

Pemanfaatan KBM selama ini baru diaplikasikan pada pakan ternak. Penelitian Teru (2017) menyatakan bahwa kadar kolesterol pada kuning telur puyuh menurun akibat penambahan tepung KBM 3\%. Oleh karena itu, perlu dilakukan penelitian aplikasi KBM pada produk pangan berupa cracker sebagai olahan non gorengan. Sehingga diharapakan mampu menciptakan cracker yang tidak hanya tinggi antioksidan, namun juga mempunyai aktifitas fungsional dalam menurunkan kolesterol.

\section{METODE PENELITIAN}

\section{Bahan}

Bahan penelitian meliputi bawang merah, tepung terigu, tepung gandum, gula aren, unsalted butter, baking powder, garam, Wistar jantan putih, pakan BR-1, sekam, air, larutan gula, lemak hewan, kuning telur, simvastatin, DPPH (1,1-difenit-2-pikrilhidrazi), etanol, aquades.

\section{Alat}

Peralatan yang digunakan antara lain alat penggiling, ayakan tepung, oven, kandang tikus dan Blood Cholesterol Meter Kits merk EasyTouch, mesin pencetak pelet, neraca analitik, gelas ukur, baskom, solet, loyang, sendok, pisau, talenan, tissue higienis, sarung, tangan karet, masker, sabun pembersih, sonde, 
spuit 5cc, kertas saring besar, pres hidrolik, sentrifuge, tabung reaksi, spektrofotometer.

\section{Pembuatan tepung kulit bawang merah}

Kulit bawang merah (KBM) yang diperoleh dari pedagang bawang merah di sekitar lokasi penelitian, dikeringkan dengan sistem sun drying selama 2 hari. Kemudian KBM yang sudah kering dihaluskan menggunakan blender dan diayak.

\section{Pembuatan cracker}

Pembuatan cracker diawali dengan menimbang bahan. Selanjutnya dicampurkan bahan-bahan kering seperti tepung gandum utuh, tepung terigu serbaguna, palm sugar, baking powder, garam dan tepung $\operatorname{KBM}$ (3, 5, dan 10\%). Setelah itu unsalted butter dimasukkan dan diaduk sampai adonan kalis. Adonan yang kalis didiamkan di dalam chiller selama 2 jam. Setelah itu, oven dipanaskan dengan suhu $150{ }^{\circ} \mathrm{C}$ dan adonan yang sudah dicetak kemudian dipanggang sampai matang kurang lebih 12 menit.

\section{Pengujian aktivitas antioksidan}

Prosedur analisa aktivitas antioksidan mengacu pada Maulani (2017). Cracker dihaluskan dan ditimbang seberat 0,1 gram. Sampel dimasukkan kedalam tube sentrifuge kemudian ditambahkan $10 \mathrm{~mL}$ etanol 99\% lalu divortex. Sampel disentrifugasi selama 10 menit dengan kecepatan 4000 rpm. Supernatan dipipet sebanyak $4 \mathrm{~mL}$ dimasukkan kedalam tabung reaksi. Sampel ditambahkan $1 \mathrm{~mL}$ larutan DPPH (1,1-diphenyl-2-picrylhydrazyl) 150 ppm. Blanko dibuat dengan $4 \mathrm{~mL}$ etanol 99\% dan $1 \mathrm{~mL}$ larutan DPPH 150 ppm. Tabung reaksi dikondisikan tertutup. Sampel kemudian diinkubasi pada suhu ruang dalam ruangan kedap cahaya selama 30 menit. Absorbansi sampel diukur pada panjang gelombang $517 \mathrm{~nm}$. Aktivitas antioksidan dihitung menggunakan rumus:

$$
\text { Aktivitas Antioksidan }(\%)=\frac{\text { Absorbansi Blako- Absorbansi Sampel }}{\text { Absorbansi Balnko }} \times 100 \%
$$

\section{Pengujian Aktivitas Antihiperkoesterolemia secara In Vivo}

\section{a. Persiapan dan Aklimatisasi Hewan Coba}

Wistar putih jantan berumur 2-3 bulan dengan berat sekitar 160-170g ditempatkan secara individu dalam 6 kandang yang masing-masing terdiri dari 5 ekor Wistar. Wistar ditempatkan pada tempat yang bersih dalam suhu kamar dengan ventilasi dan pencahayaan yang cukup. Kemudian Wistar diaklimatisasi selama 7 hari dengan pemberian air, pakan, udara, dan kondisi laboratorium. Pakan yang diberikan selama aklimatisasi adalah pakan BR-1 dan minum yang diberikan adalah air ledeng secara ad libitum (tanpa batas). Kandungan nutrisi dari pakan BR-1, berupa protein kasar 20 - 22\%; lemak kasar 5-7\%; serat kasar 
3-5\%; abu 5-7\%; Ca 0,9-1,1\%; Phospor 0,6-0,8\%; dan ME 2900-3100 kkal (Laboratorium pakan PT. Japfa Comfeed Indonesia). Kebutuhan pakan tikus berkisar 10\% dari berat badan tikus (Bintanah dan Hapsari, 2010), sehingga jika rata-rata berat badan tikus sekitar 160 g maka jumlah pakan yang dibutuhkan adalah $16 \mathrm{~g}$.

\section{b.Pemberian Induksi Pakan Tinggi Kolesterol pada Hewan Coba}

Hewan uji yang telah diaklimatisasi selama 7 hari kemudian dibagi ke dalam 2 kelompok:

a) Kelompok normal: 5 ekor Wistar tidak diberi perlakuan, hanya diberi makan pakan BR-1 dan diberi minum air. Setelah 7 hari, Wistar kemudian dilakukan uji kadar kolesterol Wistar.

b) Kelompok kolesterol: 25 ekor Wistar (kelompok uji 2, 3, 4, 5,dan 6) diberi pakan tinggi kolesterol dan diberi minum air. Pakan tinggi kolesterol terdiri dari larutan gula, lemak hewan dan kuning telur dengan rasio ketiga bahan tersebut 3:1:16. Pemberian pakan tinggi kolesterol tersebut dengan cara dilarutkan pada larutan CMC 1\% kemudian disondekan dengan dosis $0,38 \mathrm{mg} / \mathrm{kg}$ berat badan tikus. Setelah 7 hari diinduksi dengan pakan tinggi kolesterol tersebut, dilakukan uji kolesterol Wistar.

\section{c. Pemberian Pakan Perlakuan dan Pengukuran Kadar Kolesterol Darah}

Pada uji ini, selama 7 hari Wistar putih jantan diberi pakan sesuai kelompoknya sebanyak $5 \mathrm{~g}$ per tikus setiap harinya dan diberi air minum. Menurut Lingga dkk (2014) menyatakan lambung tikus maksimal menerima makanan sebanyak 5g. Adapun 6 kelompok tikus ini terdiri dari:

1. Kelompok pertama sebagai kontrol negatif merupakan kelompok tikus yang tidak diinduksi diabetes, kemudian hanya diberikan pakan BR-1

2. Kelompok kedua sebagai kontrol positif merupakan kelompok tikus yang diinduksi diabetes kemudian diberikan obat kolesterol simvastatin

3. Kelompok ketiga merupakan kelompok tikus kelompok tikus yang diinduksi kolesterol kemudian diberikan produk cracker formula P0

4. Kelompok keempat merupakan kelompok tikus yang diinduksi kolesterol kemudian diberikan produk cracker formula $\mathrm{P} 1$

5. Kelompok kelima merupakan kelompok tikus yang diinduksi kolesterol kemudian diberikan produk cracker formula P2

6. Kelompok keenam merupakan kelompok tikus yang diinduksi kolesterol kemudian diberikan produk cracker formula P3

Pada kelompok kontrol negatif dan positif, tikus diberikan pakan BR-1. Namun pada kelompok kontrol positif diberikan simvastatin sebagai obat kolesterol dengan dosis $0,18 \mathrm{mg} / \mathrm{kg}$ berat badan tikus dengan cara disonde. Pada kelompok perlakuan, tikus diberikan cracker formula P0, P1 P2, dan P3. Selanjutnya Wistar diukur kadar kolesterol darah di hari ke-7 dengan cara 
mengambil darah melalui pembuluh darah ekor kemudian darah dicek menggunakan Blood Cholesterol Meter Kits. Persentase penurunan kolesterol akibat perlakuan dihitung dengan cara selisih kolesterol pasca induksi antara hari ke-0 dan ke-7, dibagi kolesterol hari ke-0 kemudian dikalikan $100 \%$.

\section{Rancangan Percobaan dan Analisa Data}

Penelitian ini menggunakan rancangan eksperimental laboratorik dengan pola post-test only control group design. Pengujian dilakukan secara in vivo yang sudah disetujui oleh Komisi Etik Penelitian Kesehatan Universitas Muhammadiyah Malang dengan no surat E.5.a/110/KEPK-UMM/2019. Pengujian ini menggunakan hewan coba sebanyak 30 ekor sebagai unit percobaan dibagi menjadi 6 kelompok (2 kelompok control, 4 kelompok perlakuan), sehingga masing-masing terdiri dari 5 ekor tikus. Penentuan besar sampel menurut rumus Freeder yakni dengan jumlah sampel minimal 4 wistar untuk setiap kelompoknya. Data semua parameter yang terkumpul dikelompokkan berdasarkan perlakuan kemudian dilakukan analisis secara deskriptif dengan menampilkan Tabel menurut kelompok intervensi.

\section{HASIL DAN PEMBAHASAN}

\section{Aktivitas Antioksidan Cracker dengan Penambahan Tepung KBM}

Pengujian aktivitas antioksidan perlu dilakukan karena antioksidan mengurangi stress oksidatif yang diakibatkan oleh kerusakan oksidatif dari lipid tidak jenuh ganda yang melibatkan reactive oxygen species (ROS) dan ion logam transisi (Hogg et al. 1961; Cao et al. 1966 dalam Shalaby dan Shanab 2013). Pada penelitian ini, tepung KBM mempunyai aktivitas antioksidan sekitar $60 \%$ (Tabel 1). Hal ini sesuai dengan literatur Mardiah dkk (2017) yang menyatakan bahwa aktivitas antioksidan KBM sekitar $61,75 \%$.

Jika dibandingkan dengan aktivitas antioksidan dari bahan lain, maka nilai aktivitas antioksidan KBM lebih rendah dibandingkan dengan bekatul (71,74-73,95\%) (Zubaidah dkk, 2012) dan kulit buah naga (76,71\%) (Hidayah, 2013), tetapi hampir setara dengan ubi jalar ungu (59,25\%) (Husna dkk, 2013). Aktivitas antioksidan tepung KBM ini diduga berasal dari senyawa flavonoid. Menurut Rodriguez (2003), KBM mengandung bahan aktif berupa flavonoid, saponin, minyak atsiri, aliin dan alisin, kuersetin. Flavonoid inilah yang memiliki antioksidan alamiah yang dapat menurunkan kadar kolesterol jahat (LDL) dalam darah secara efektif (Jaelani, 2007).

Sementara pada cracker yang telah ditambahan tepung KBM dengan berbagai konsentrasi menunjukkan bahwa semakin besar presentase tepung KBM yang ditambahkan pada cracker, maka aktivtas antioksidan semakin tinggi. Jika dibandingkan antara tepung KBM dan cracker formula P3 (10\% 
tepung KBM), maka aktivitas antioksidan pada cracker P3 lebih tinggi dibandingkan tepung KBM. Hal ini diduga ada kontribusi aktivitas antioksidan dari bahan baku pembuatan cracker yakni palm sugar dan tepung gandum utuh. Menurut Winarni (2018), palm sugar mempunyai aktivitas antioksidan sekitar 80\%, sedangkan tepung gandum mempunyai aktivitas antioksidan sekitar 31,90\% (Okarter, 2010).

Tabel 1. Hasil aktivitas antioksidan tepung kulit bawang merah dan cracker

\begin{tabular}{l|r}
\hline Perlakuan & \multicolumn{1}{|c}{$\begin{array}{c}\text { Aktivitas } \\
\text { Antioksidan (\%) }\end{array}$} \\
\hline Tepung kulit bawang merah & 60,52 \\
Cracker Formula P0 (0\% tepung kulit bawang merah) & 39,60 \\
Cracker Formula P1 (3\% tepung kulit bawang merah) & 43,60 \\
Cracker Formula P2 (5\% tepung kulit bawang merah) & 46,44 \\
Cracker Formula P3 (10\% tepung kulit bawang merah) & 68,90 \\
\hline
\end{tabular}

\section{Aktivitas Antihiperkolesterolemia Cracker dengan Penambahan Tepung KBM}

Selama hewan coba diberi perlakuan pakan, banyak tikus yang mati yang diduga karena faktor stress. Oleh karena itu, nilai kolesterol total hanya dihitung dari rata-rata 3 ekor tikus per kelompok perlakuan. Pengaruh pemberian cracker dengan penambahan tepung KBM pada tikus Wistar yang diinduksi pakan tinggi kolesterol tersaji pada Tabel 2.

Pada Tabel 2 menunjukkan bahwa pada pre induksi, kolesterol total Wistar untuk semua kelompok berkisar pada $120-150 \mathrm{mg} / \mathrm{dL}$. Nilai ini menunjukkan kolesterol pada tikus sebelum diinduksi dikategorikan normal, karena menurut Nurmeilis (2015) kondisi normal kolesterol tikus berada pada kisaran 40-150 mg/dL. Kemudian pasca diinduksi, pada kelompok kontrol negatif (tidak diinduksi pakan tinggi kolesterol) yang hanya diberi pakan BR-1, nilai kolesterol total masih dikategorikan normal karena masih berkisar antara 120$150 \mathrm{mg} / \mathrm{dL}$. Sedangkan pada 5 kelompok lainnya (kecuali kelompok P1), Wistar yang dikondisikan hiperkolesterolemik menunjukkan kolesterol total berkisar antara 160-245 mg/dL. Tikus dinyatakan hiperkolesterolemik apabila kadar kolesterol >150 mg/dL. Kenaikan kolesterol pasca induksi dikarenakan komponen penyusun pakan induksi yakni 80\% terdiri dari kuning telur yang mempunyai kandungan kolesterol pada kuning telur terendah sebesar 682.20 $\pm 5.30 \mathrm{mg} / \mathrm{dL}$ (Teru dkk, 2017). 
Tabel 2. Rerata kadar kolesterol total tikus (mg/dL)

\begin{tabular}{l|c|c|c|l}
\hline \multicolumn{1}{c|}{ Perlakuan } & $\begin{array}{c}\text { Sebelum } \\
\text { induksi pakan } \\
\text { tinggi } \\
\text { kolesterol }\end{array}$ & $\begin{array}{c}\text { Setelah } \\
\text { Induksi pakan } \\
\text { tinggi kolesterol }\end{array}$ & $\begin{array}{c}\text { Hari ke-7 } \\
\text { pasca } \\
\text { perlakuan }\end{array}$ & Penurunan \\
\hline Kontrol negatif (pakan BR-1) & $147,50 \pm 23,33$ & $133,67 \pm 18,77$ & $151,00 \pm 11,00$ & - \\
Kontrol positif (simvastatin) & $145,50 \pm 9,19$ & $162,33 \pm 11,68$ & $149,40 \pm 47,50$ & 7,96 \\
P0 (Cracker 0\% tepung KBM) & $135,50 \pm 17,68$ & $245,00 \pm 11,79$ & $225,67 \pm 23,50$ & 7,88 \\
P1 (Cracker 3\% tepung KBM) & $135,00 \pm 24,04$ & $134,67 \pm 32,25$ & $180,33 \pm 36,91$ & - \\
P2 (Cracker 5\% tepung KBM) & $128,00 \pm 35,36$ & $170,00 \pm 79,90$ & $208,67 \pm 60,38$ & - \\
P3(Cracker 10\% tepung KBM) & $154,50 \pm 3,54$ & $166,67 \pm 39,00$ & $149,00 \pm 8,03$ & 10,60 \\
\hline
\end{tabular}

Pada hari ke-7 pasca perlakuan, kelompok kontrol negatif menunjukkan nilai kolesterol total yang normal dikarenakan hanya diberikan aquades saja tanpa pakan perlakuan. Pada kelompok kontrol positif, kolesterol total tikus hampir kembali ke nilai normal, dikarenakan pemberian obat kolesterol berupa simvastatin. Simvastatin merupakan obat kolesterol yang bekerja di dalam tubuh dengan cara menghambat 3-hydroxy-3-methylglutaryl koenzim A (HMGCoA) reduktase. Simvastatin merupakan antihiperlipidemia yang kuat terutama dalam menurunkan kadar LDL yaitu sampai 50\% (Sukrama, 2014). Akan tetapi persentase penurunan kolesterol total tikus akibat pemberian simvastatin $(7,80 \%)$ hampir sebanding dengan produk cracker tanpa tepung KBM (P0). Sementara dosis yang digunakan pada penelitian ini sudah sesuai dengan Artha dkk (2017) yang menyatakan bahwa dosis simvastatin yang dipakai adalah $0,36 \mathrm{mg} / \mathrm{kg}$ berat badan. Rendahnya penurunan kolesterol total pada kelompok kontrol positif diduga dikarenakan stress pada tikus hewan coba. Berdasarkan Sayekti (2014), stress mengakibatkan pemebersihan lipid dalam darah menurun sehingga terjadi penumpukan LDL dalam darah sehingga efek antihiperlipidemia kurang mampu menurunkan LDL.

Pada kelompok tikus perlakuan P1 dan P2, data menunjukkan tren peningkatan kolesterol total pasca 7 hari mengkonsumsi cracker dengan penambahan tepung KBM 3 dan 5\%. Sementara pada kelompok perlakuan P3, kolesterol total tikus menurun sampai $10 \%$ pasca 7 hari mengkonsumsi cracker dengan penambahan tepung KBM 10\%. Perbedaan tren antara kelompok P1, P2, dan P3 diduga karena kondisi stress pada tikus. Kortisol yabg dilepaskan selama stres akan menyebabkan kadar glukosa darah meningkat. Hal ini akan memicu glukoneogenesis pada hati, sehingga simpanan kolesterol pada jaringan lemak akan dilepaskan dalam darah (Dharmayanti, 2012).

Penurunan kolesterol pada kelompok perlakuan P0 dan P3 dikarenakan aktivitas antioksidan dari bahan pembuatan cracker tersebut. Pada cracker P0, palm sugar dan tepung gandum memiliki aktivitas antioksidan yang cukup 
dipertimbangkan. Adanya serat pada tepung gandum juga berpotensi sebagai senyawa yang mampu menurunkan kolesterol. Serat yang terkandung pada tepung gandum sekitar 11,8 g/100 g (Souza et al., 2011). Serat makanan mampu mengikat asam empedu sehingga jumlah asam empedu bebas akan berkurang. Kondisi ini mendorong pembentukan asam empedu baru yang berasal dari kolesterol yang ada dalam darah sehingga kolesterol dalam darah akan menurun (Saraswati et al., 2013).

Sedangkan pada cracker P3, tepung KBM yang ditambahkan meningkatkan aktivitas antioksidan (Tabel 2). Menurut Rodriguez (2003), KBM mengandung bahan aktif salah satunya flavonoid sebagai antioksidan. Flavonoid berperan dalam penghambatan aktivitas enzim MHG $\mathrm{KoH}$ reduktase dalam biosintesis kolesterol sehingga kadar kolesterol total menurun. Selain itu, flavonoid sebagai kofaktor enzim kolesterol esterase dan inhibitor absorbsi kolesterol dapat menghambat penyerapan kolesterol melalui pembentukan misel (Oliveira et al., 2007).

Kemampuan formula cracker P3 (penambahan tepung KBM 10\%) dalam menurunkan kolesterol menunjukkan hasil yang lebih besar jika dibandingkan nugget tempe yang hanya mampu menurunkan kolesterol pada tikus hiperkolesterol sampai 8,38\% (Handarsari, 2014). Namun lebih rendah jika dibandingkan dengan yoghurt kedelai hitam yang menurunkan kolesterol 31,06\% (Baiduri, 2011).

\section{KESIMPULAN}

Kesimpulan yang dapat ditarik dari penelitian ini adalah formulasi cracker dengan penambahan tepung KBM 10\% (P3) mampu menurunkan kolesterol paling tinggi yakni sekitar 10\%. Selain itu formula P3 juga mempunyai aktivitas antioksidan tertinggi berkisar 68\%. Hal ini menunjukkan bahwa produk cracker dengan penambahan tepung KBM berpotensi dijadikan pangan fungsional tinggi antioksidan dan mempunyai aktivitas antihiperkolesterolemia.

\section{UCAPAN TERIMA KASIH}

Terima kasih diucapkan kepada KEMRISTEKDIKTI yang mendanai penelitian ini melalui Universitas Muhammadiyah Malang.

\section{REFERENSI}

Andriani, Y. 2007. Uji Aktivitas Antioksidan Ekstrak Betaglukan dari Saccharomyces cerevisiae. Journal Gradien. 3(1):226-230

Artha, C., Mustika,A., dan Sri, W.S. 2017. Pengaruh Ekstrak Daun Singalawang terhadap Kadar LDL Tikus Putih Jantan Hiperkolesterolemia. Artikel Penelitian. Fakultas Kedokteran Universitas Airlangga. Vol 5 No 2 
Baiduri, I. 2011. Pengaruh Pemberian Yoghurt Kedelai Hitam (Black Soyghurt) terhadap Kadar Trigliserida Serum pada Tikus Hiperkolesterolemia. Skripsi. Program Studi Ilmu Gizi Fakultas Kedoketran Universitas Diponegoro

Bintani, S dan Hapsari, S.K. 2010. Pengaruh Pemberian Bekatul dan Tepung Tempe Terhadap Profil Gula Darah Pada Tikus yang Diberi Alloxan. Jurnal Pangan dan Gizi Vol 01 No. 02

Depkes RI., 2007. Pedoman Pengendalian Penyakit Jantung dan Pembuluh darah. Departemen Kesehatan RI: Jakarta

Dharmayanti, A.W.S. 2012. Pengaruh Stresor Renjatan Listrik Pada Kadar Kolesterol Total Pada Serum Tikus Jantan (Rattus Norvegicus) Strain Wistar. Jurnal Kedokteran Gigi Universitas Negeri Jember Vol 9. No. 1 2012: 54-57

Handarsari,E. 2014. Pengaruh Pemberian Nugget Furfures Soybean Tempeh Terhadap Penurunan Kadar Kolesterol Total Dan Peningkatan HdL Tikus Putih (Rattus Norvegicus) Dislipidemia. Jurnal Fakultas Kesehatan Universitas Muhammadiyah Semarang: Semarang

Hidayah, T.2013. Uji Stabilitas Pigmen dan Antioksidan Hasil Ekstraksi Zat Warna Alami Dari Kulit Buah Naga (Hylocereus undatus). Skripsi. Fakultas Matematika dan Ilmu Pengetahuan Alam. Universitas Negeri Semarang

Husna, E.L., Novita, M., Rohaya, S.2013. Kandungan antosianin dan aktivitas antioksidan ubi jalar ungu segar dan produk olahannya. Agritech, Vol 33. No 3

Jaelani. 2007. Khasiat bawang merah. Yogyakarta: Kanisius. 16-26.

Lingga, I.S., Citraningtyas, G., dan Lolo, W.A. 2014. Uji Efek Ekstrak Etanol Patikan Kebo (Euphorbia hirta Linn.) Sebagai Diuretik pada Tikus Putih Jantan Galur Wistar (Rattus norvegicus sp.). Jurnal Ilmiah Farmasi. Vol 3 No.3

Mardiah,N., Catherina, M., Audifa, A., Lisnawati, Dyah, A., Dina, R. 2017. Penentuan Aktivitas Antioksidan dari Ekstrak Kulit Bawang Merah (Allium ascalonicum L.) Dengan Metode DPPH. Jurnal Pharmascience, Vol. 04, No.02,147- 154

Marianti, A. 2013. Aktivitas Antioksidan Madu Floral terhadap Profil Lipid Darah Tikus Putih Hiperlipidemik. Jurnal Sains dan Teknologi. 11(I):7-8

Maulani, SM. 2017. Pengaruh Rasio Daging dan Kulit Buah Naga Merah (Hylocereus Costaricensis) dan Penambahan Jenis Gula Terhadap Mutu Selai. Skripsi. Fakultas Pertanian Peternakan. Universitas Muhammadiyah Malang. Malang

Nurmeilis. 2015. Penentuan Profil Lipid-kolesterol pada Tikus Normal dan Tikus Hiperkolesterol setelah Pemberian Ekstrak Herba Kumis Kucing (Orthosiphon stamineus). Pusat Penelitian dan Penerbitan LP2M UIN Syarif Hidayatullah : Jakarta

Okarter,N. 2010. Phytochemical content and antioxidant activity of six diverse varieties of whole wheat. Journal of Food Chemistry 119 (2010) 249-257 
Oliveira, T.T., Kelly F.S. Ricardo, Márcia R.Almeida, Marcelo R.Costa, and Tanus J. Nagem. 2007. Hypolipidemic Effect of Flavonoids and Cholestyramine in Rats. Lat. Am. J. Pharm. 26 (3): 407-10

Patras A., Tiwari B. K,. \& Brunton N. P. 2010. Influence of Blanching and Low Temperature Preservation Strategies on Antioxidant Activity and Phytochemical Content of Carrots, Green Beans and Broccoli. LWT - Food Science and Technology, $44: 299-306$

Rahayu, S., Nunung, K., dan Vina, A. 2015. Ekstraksi dan Identifikasi Senyawa Flavonoid dari Limbah Kulit Bawang Merah sebagai Antioksidan Alami. Al Kimiya, Vol. 2, No. 1

Rodriguez A. 2003. Nutrition Value of Onion Regional Varieties in Northwest Portugal. EJEAFChe 2(4):519-524.

Saraswati, T, R, Manalu, W, Ekastuti, D, R, Kusumorini, N. 2013. The role of tur-meric powder in lipid metabolism and its effect on quality of the first quail's egg. J. Indonesian Trop. Anim. Agric. 38(2):123-130

Sayekti, N.A. 2014. Pengaruh Pemberian Yoghurt Koro Pedang (Canavalia ensiformis) terhadap Kadar Kolesterol LDL dan HDL Serum Tikus Sprague Dawley Dislipidemia. Journal of Nutrition College. Vol 3, No 1, 125-133

Shalaby EA, Shanab SMM. 2013. Antioxidant compounds, assays of determination and mode of action. Afr J Pharm Pharmacol. 7(10):528-539.

Souza, E. J., and Sneller, C. 2011. Laboratory milling method for whole grain soft wheat flour evaluation. Cereal Chem. 88:1-5

Sukrama, D.M. 2014. Simvastatin Generic (Generic Simvastatin). Indonesian Journal Of Clinical Pathology And Medical Laboratory Vol. 20, No. 2.

Teru, V., M.H. Natsir, Eko, W. 2017. Pemanfaatan Tepung Kulit Bawang Merah (Allium ascalonicum) Sebagai Imbuhan Pakan Terhadap Penampilan, Profil Darah Dan Kolesterol Pada Puyuh Petelur. Jurnal Ilmu-Ilmu Peternakan 27 (3): $76-82$

Zubaidah, E., Saparianti, E.,dan Hindrawan, J. 2012. Studi Aktivitas Bekatul dan Susu Skim Terfementasi Probiotik (Lactobacillus plantarum B2 dan Lactobacillus acidophilus). Jurnal Teknologi Pertanian.Vol 13 No 2,111-118 